\title{
Johtamisen dynamiikka ja psykologiaa
}

\author{
Pauli Juuti: Johtaminen ja organisaation alitajunta. Aavaranta-sarja no: 38. Otava, Helsinki \\ 1995, 222 sivua. \\ Unto Pirnes: Kehittyvä johtajuus - Johtamisen dynamiikka. Aavaranta-sarja no: 36. Otava, \\ Helsinki 1995, 222 sivua.
}

Suomi on ollut suossa viimeksi kuluneet viisi vuotta. Kansantalous on kokenut syvän laman, jonka seurauksena työelämää on rationalisoitu rajusti, myös työttömyys on edelleen ennätyksellisen suurta. Mikä ajoi yhteiskuntamme taloudelliseen ja yhteiskunnalliseen kriisiin? Onko taustalla Neuvostoliiton romahdus, tehottomat investoinnit, laiskat työntekijät vai taitamattomat johtajat? Laman syitä on varmaan useampia, mutta viime vuonna julkaistuissa kirjoissaan johtamistaidon opiston opettajat ja tutkijat Pauli Juuti ja Unto Pirnes sivuavat aihetta pureutumalla suomalaisen johtajuuden kehittämiskysymyksiin.

\section{Johtaminen ja organisaation muutos}

Pauli Juuti pohtii kirjassaan organisatorisen muutoksen taustoja. Hän kääntää katseensa psykologisesti organisaatioiden sisään. Juuti nimeää kolme johtamisen ongelmaa, joihin kaivataan kipeästi ratkaisuja. Ensimmäinen ongelma koskee karismaattisen ja osallistuvan johtajuuden suhdetta. Miten huomioida erilaisuus ja miten saavuttaa yhtenevä näkemys ja yhteneväiset työskentelytavat samanaikaisesti? Toinen koskee valtaa. Miksi ajattelutapoja ei voida uudistaa ja johtajia vaihtaa joustavasti, miksi muutosten täytyy aina olla niin rajuja? Kolmas ongelma koostuu yksilöiden ja kulttuurin kehittämisen tarpeesta ja mahdollisuuksista.

Jotta vastauksia mainittuihin kysymyksiin voitaisiin löytää, olisi juutin mielestä siirryttävä asioiden johtamisesta merkityksien ja luovien ihmisten johtamiseen. Juuti analysoi suomalaisten (yritys)organisaatioiden tilaa käyttäen hyväkseen mm. freudilaisen psykologian käsitteitä. Organisaatioiden kehitys kulkee oraalisesta vaiheesta monien eri kehitysvaiheiden kautta tiettyyn malliin. Ihannetapauksessa lopputuloksena on aikuismainen, yksilöllisyyden ja yhteistyön kulttuuri.

Organisaatioiden kasvu edellyttää myös yksilöiden kasvua. Tässä prosessissa avainasemassa ovat johtajat. Tarvitaan johtajien persoonallisuuden kasvua johtamisen ja työyhteisöjen kehittymisen ehtona. Selviytyminen merkitsee jatkuvaa innovatiivisuutta. Dogmaattinen jäykkyys johtaa tuhoon ja innovatiivinen johtajuus taas menestykseen. Siksi eilisen kilpailutilanteet tuleekin unohtaa ja johtajien olisi keskityttävä huomisen haasteisiin.

Unto Pirnesin kirja puolestaan pohtii johtamisen dynamiikkaa, johtamiskäyttäytymistä ja johtajana kehittymistä. Tekijä korostaa ajattelutapaa, jossa hyvän johtajan piirteissä yhdistyvät kyky huomoida ympäristön vaateet ja oma persoonallisuus. Siten johtajuuden kehittäminen on sekä johtajien käyttäytymisen tukemista että johtajien käyttäytymisen ja ympäristön vaatimusten yhteensopivuuden parantamista.

Kyse on oppimisprosessista, jossa avainasemassa on johtaja. Kehittyvään johtajuuteen sitoutunut johtaja luo työyhteisöönsä oppivan johtamiskulttuurin. Kehittyvä johtaja on avoin uudelle. Oppimansa uudet asiat hän vie käytäntöön, kokeilee niitä ja oppia kokemuksista. Hyvät johtajat saavat aikaan kehittymistä ja kasvua itsessään, organisaatioissaan ja johdannossaan ihmisissä. He tekevät hyviä tuloksia johtamiensa ihmisten avulla. 
Sekä juutin että Pirnesin kirjat perustuvat pitkään kokemukseen suomalaisten yritysjohtajien (jatko)kouluttamisessa. Taustalla on paitsi koulutusta myös johtamista käsittelevää tutkimusta. Etenkin Pirnesin kirjassa on raportoitu sangen kiinnostavia tuloksia JTO:n suomalaisia johtajia koskevista tutkimuksista. Lisäksi lukijan on pidettävä mielessä, että kirjat on tarkoitettu ennen kaikkea itseään kehittävien johtajien käyttöön, johtamisen apuvälineiksi.

Tällaisen taustan valossa kirjat puoltavat paikkaansa. Johtajilta puuttuu ihmistieteellistä osaamista. Suomalainen johtaja on asiajohtaja, joka tuntee tekniikan ja talouden, mutta joka on ymmällään kohdatessaan ihmisen. Sen sijaan yhteiskuntatieteilijä, joka tutustuu kirjoihin, on kriittisempi. Juuti harjoittaa organisatorista psykoanalyysiä. Myös Pirnesin kirjassa keskitytään yksilöön, johtajan kehitykseen, avoimuuteen ja oppimiseen. Psykologisoivan ja yksilöllistävän ajattelutavan mukaan työelämän pullonkauloista ei päästä eroon kuin tuskallisen kokemisen ja oppimisen jälkeen. Avainasemaan nostetaan johtaja. Hän määrittää koko organisaatiota ja sen muutosta. Nähdäkseni monet työelämää analysoivat sosiologiset tutkimukset kuitenkin osoittavat, että melko yksinkertaisillakin rakenteellisilla ratkaisuilla voi saada paljon hyvää aikaan. Tarvitaan vain perustietoja.

Tässä onkin yksi suomalaisen johtamiskoulutuksen ongelma. Meillä yritysjohtajien koulutuksessa ei kiinnitetä riittävästi huomiota yhteiskuntatieteelliseen osaamiseen ja yhteiskuntatieteellisen tiedon soveltamiseen työelämässä. Tämä lukeneisuuden puute näkyy hyvin myös Juutin ja Pirnesin kirjoissa. Sosiologia käsitetään johtamisopeissa vanhahtavasti käyttäytymistieteeksi, josta voi mahdollisesti olla jotakin hyötyä, mutta jota ei kuitenkaan ole syytä johtajille opettaa.

Psykoanalyysin sijaan johtamiskoulutuksessa ja käytännön oppaissa tulisi avata uusia käsitteellisiä maailmoja. Sosiaalinen vuorovaikutus, arvo, intressi, sosiaalinen toiminta tai valta, ne kaikki ovat sosiologian peruskäsitteitä, jotka voivat auttaa johtajuuden kehittämisessä ja organisaation (itse)tietoisuuden kasvattamisessa. Se edellyttää kuitenkin koulutuksen avartamista. Uskon sen kannattavan. 